\title{
Denitrification in cropping systems at sub-zero soil temperatures. A review
}

\author{
Rebecca L. PHILLIPS* \\ USDA-ARS, Box 459, Mandan, ND 58554, USA
}

(Accepted 26 September 2007)

\begin{abstract}
Nitrogen (N) in agricultural fertilizers is denitrified by soil bacteria when oxygen is limited, which effectively removes plantavailable $\mathrm{N}$ from the soil to the atmosphere. Reported denitrification rates range from 0 to $239 \mathrm{~kg} \mathrm{~N} \mathrm{ha}^{-1} \mathrm{yr}^{-1}$, and, depending upon environmental conditions and management, may reduce the amount of $\mathrm{N}$ available for crop growth by $27 \%$. Denitrification in soils also results in emissions of nitrous oxide $\left(\mathrm{N}_{2} \mathrm{O}\right)$, which is a recognized pollutant that contributes to stratospheric ozone destruction and radiative forcing in the troposphere. Practitioners of sustainable agronomy aim to improve plant $\mathrm{N}$-use efficiency and reduce emissions of the greenhouse gases by synchronizing $\mathrm{N}$ application and plant nutritional requirements. However, it is difficult to predict denitrification rates during and after the growing season based on current knowledge. High rates are consistently reported in irrigated cropping systems following heavy applications of fertilizer-N, but few studies report denitrification during the dormant season. Denitrification in winter may represent a significant sink for fertilizer- $\mathrm{N}$ in cropping systems, but further research at sub-zero soil temperatures is needed. Here, the three factors required for microbial denitrification: limited $\mathrm{O}_{2}$ availability, electron donors and electron acceptors, are reviewed based on soil research performed both above and below $0{ }^{\circ} \mathrm{C}$. Gaps in the knowledge of denitrification rates in cropping systems, particularly when soils are frozen, are identified. Sustainable management of $\mathrm{N}$ in cropping systems such as greater $\mathrm{N}$-use efficiency and lower greenhouse gas emissions could be advanced by greater understanding of denitrification in winter.
\end{abstract}

nitrous oxide / sub-zero temperatures / nitrogen / fertilizer

\section{INTRODUCTION}

The greatest agronomic uncertainty in balancing the nitrogen $(\mathrm{N})$ budget of agricultural landscapes is the rate of denitrification, which converts plant-available $\mathrm{N}$ into gaseous $\mathrm{N}$ (Galloway et al., 2004). Specifically, it is not known when denitrification in the rooting zone reduces the availability of $\mathrm{N}$ to crops or the magnitude of $\mathrm{N}$ losses via denitrification. Current average $\mathrm{N}$-use efficiency in cropping systems (\% recovery of applied $\mathrm{N}$ ) is reported to range from 30-50\% (Cassman et al., 2002). A major reason for low N-use efficiency is the loss of gaseous-N from agricultural soils worldwide (Davidson and Seitzinger, 2006). Denitrification may transfer up to $27 \%$ of agricultural $\mathrm{N}$ back to the atmosphere (Bouwman et al., 2005). However, spatial and temporal heterogeneity in denitrification rates, lack of quantitative data and inconsistencies between laboratory versus field measurements contribute to uncertainties in the rate of denitrification, despite decades of research (Davidson and Seitzinger, 2006).

Achieving synchrony between $\mathrm{N}$ supply and crop demand without sacrificing yield or protection of the environment requires greater knowledge of denitrification rates, yet knowledge of denitrification during the dormant season is limited. In many cases, gaseous-N losses at sub-zero soil temperatures are unknown or considered negligible. Consequently, wintertime

\footnotetext{
* Corresponding author: Rebecca.phillips@ars.usda.gov
}

$\mathrm{N}$ losses are rarely considered in crop fertilization recommendations. The body of evidence suggests microbes are physiologically active when soils are frozen (Clein and Schimel, 1995; Mikan, 2002; Price and Sowers, 2004; Rivkina et al., 2000), calling for agronomists to question what is known about the physicochemical and biological properties of soil below $0{ }^{\circ} \mathrm{C}$. Microbial emissions of $\mathrm{N}_{2} \mathrm{O}$ and $\mathrm{N}_{2}$ occur at subzero soil temperatures (Phillips, 2007; Röver et al., 1998), but processes controlling denitrification rates in frozen soils are currently unknown. Gaps in the knowledge below $0{ }^{\circ} \mathrm{C}$ need to be filled because there may be unforeseen opportunities for conservation of fertilizer- $\mathrm{N}$ and for reductions in greenhouse gas emissions during winter.

Denitrification is a ubiquitous process, occurring globally in both terrestrial and aquatic ecosystems (Davidson and Seitzinger, 2006). This review focuses on denitrification through the process of anaerobic microbial respiration known to occur in sub-oxic soil microsites (Myrold and Tiedje, 1985; Parkin, 1987) specifically in cropped soils. Other, nonrespiratory pathways observed in aquatic systems (e.g. chemodenitrification, aerobic ammonium oxidation) are outside the scope of this review (Hulth et al., 1999; Kuypers et al., 2005). Three fundamental factors are required for anaerobic microbial denitrification: (1) sub-oxic or anoxic conditions (herein referred to anoxic), (2) electron donors (herein referred to as organic C), and (3) electron acceptors nitrite $\left(\mathrm{NO}_{2}^{-}\right)$or nitrate $\left(\mathrm{NO}_{3}^{-}\right)$, (herein referred to as $\mathrm{NO}_{3}^{-}$). Each factor is reviewed 
separately with respect to denitrification when soil temperatures are greater or less than $0{ }^{\circ} \mathrm{C}$. Research that is necessary to unravel how denitrification might occur at sub-zero soil temperatures is proposed.

\section{DENITRIFICATION OVERVIEW}

Denitrification is classically defined as the microbial oxidation of organic matter, where $\mathrm{NO}_{3}^{-}$is the terminal electron acceptor. It is a heterotrophic process of anaerobic respiration conducted by facultative bacteria using oxidized forms of $\mathrm{N}$ to accept electrons when $\mathrm{O}_{2}$ is limited (Firestone et al., 1980). The end product is $\mathrm{N}_{2}$, but some intermediate compounds (such as $\mathrm{N}_{2} \mathrm{O}$ and $\mathrm{NO}$ ) may also be produced, depending upon environmental conditions (Firestone and Davidson, 1989). The primary factor controlling the rate of denitrification is $\mathrm{O}_{2}$ availability because in sub-oxic conditions $(<0.2 \mathrm{mg}$ $\mathrm{O}_{2} \mathrm{~L}^{-1}$ ), some facultative microbes that normally use $\mathrm{O}_{2}$ as an electron acceptor will use $\mathrm{NO}_{3}^{-}$(Firestone et al., 1980; Seitzinger et al., 2006). Sub-oxic, as defined here, is three orders of magnitude lower than the density of $\mathrm{O}_{2}$ in moist air $\left(290 \mathrm{mg} \mathrm{O}_{2} \mathrm{~L}^{-1}\right)$. Numerous laboratory incubation studies indicate that, for similar soils incubated at a constant temperature, denitrification rates can be manipulated by varying percent water-filled pore space (\%WFPS), electron donors, and electron acceptors (Firestone and Davidson, 1989; Myrold and Tiedje, 1985; Sexstone et al., 1988). Numerous field studies indirectly point to these factors by reporting how differences in drainage $\left(\mathrm{O}_{2}\right.$ status), soil organic matter form and quantity (electron donors), and fertilization form and application (electron acceptors) alter rates of denitrification (Aulakh et al., 1984, 2001; Hofstra and Bouwman, 2005). Accordingly, for a given soil and temperature, the kinetics of denitrification can largely be explained by these three factors.

An intermediate gaseous product of denitrification, $\mathrm{N}_{2} \mathrm{O}$, has received a great deal of attention (Bouwman et al., 1995; Davidson et al., 2000; Dobbie et al., 1999; Dobbie and Smith, 2003; Jungkunst et al., 2006) because of its importance in the processes of ozone destruction and radiative forcing (Prather et al., 2001). The global warming potential of $\mathrm{N}_{2} \mathrm{O}$ is nearly 300 times greater than $\mathrm{CO}_{2}$ by mass (Forster et al., 2007). Two soil microbial processes, nitrification and denitrification typically produce this gas, so $\mathrm{N}_{2} \mathrm{O}$ fluxes measured at the soil surface are not necessarily products of denitrification. Losses resulting from complete reduction of $\mathrm{NO}_{3}^{-}$to $\mathrm{N}_{2}$ are rarely measured because the large atmospheric background of $\mathrm{N}_{2}$ makes it analytically difficult to detect small increases in $\mathrm{N}_{2}$ from denitrification (Davidson and Seitzinger, 2006).

While knowledge is growing with respect to cropping systems and surface fluxes of $\mathrm{N}_{2} \mathrm{O}$ in winter (Kaiser et al., 1998; Maggiotto and Wagner-Riddle, 2001; Wagner-Riddle et al., 1997), measurements of total gaseous losses of $\mathrm{N}$ via denitrification in frozen soils are lacking. Observed fluxes of $\mathrm{N}_{2} \mathrm{O}$ at the surface of frozen soils suggest microbial denitrification may occur at sub-zero soil temperatures (Röver et al., 1998) but specific mechanisms are unknown. One question is: how much total $\mathrm{N}\left(\mathrm{N}_{2} \mathrm{O}+\mathrm{N}_{2}\right)$ is from denitrification below $0{ }^{\circ} \mathrm{C}$ and how much is degassed from accumulated products of denitrification prior to freezing?

Current knowledge of how management influences denitrification rates is largely garnered from experiments conducted during the growing season and at laboratory temperatures. Many field and laboratory experiments are conducted by manipulating the three factors required for denitrification $\left(\mathrm{O}_{2}\right.$ status, organic $\mathrm{C}, \mathrm{NO}_{3}^{-}$). For example, greater denitrification rates are found in fertilized cropped soils at high \%WFPS (Barton et al., 1999; Hofstra and Bouwman, 2005) because $\mathrm{O}_{2}$ diffusion is restricted under saturated conditions and the proportion of soil volume that is anoxic increases (Sexstone et al., 1985; Smith, 1980). In some cases, organic $\mathrm{C}$ and $\mathrm{N}$ additions will increase denitrification rates (Burford and Bremner, 1975; Myrold and Tiedje, 1985; Paul et al., 1993). Fertilizer$\mathrm{N}$ and residue inputs might fuel denitrification in frozen soils at high moisture levels during the winter, but empirical studies are needed to estimate $\mathrm{N}$ transformation rates and controls in frozen soil. Filling these knowledge gaps during the winter will improve agronomic recommendations, with potentially positive economic and environmental benefits.

\section{WATER-FILLED PORE SPACE IN FROZEN SOIL}

Application of soil \%WFPS (Eq. (1)) as a proxy for soil $\mathrm{O}_{2}$ status is fundamental to current models of denitrification (Firestone and Davidson, 1989).

$\%$ WFPS $=\left(\theta_{v} / \phi\right) \times 100$

where $\theta_{v}=$ percent volumetric water content, $\theta_{m} \times \rho_{b}$;

$\phi=$ percent total porosity $=\left(1-\rho_{b} / \rho_{p}\right) \times 100$;

$\theta_{m}=$ percent gravimetric water content;

$\rho_{b}=$ soil bulk density $\left(\mathrm{mg} \mathrm{m}^{-3}\right)$;

$\rho_{p}=$ soil particle density $\left(\sim 2.65 \mathrm{mg} \mathrm{m}^{-3}\right)$.

It is a well accepted approximation that at soil \%WFPS $>70$ (where water is liquid), gaseous $\mathrm{N}$ emissions are the result of microbial denitrification (Bateman and Baggs, 2005; Davidson, 1991), although exact \%WFPS values vary with soil mineralogy. It is less clear how \%WFPS influences microbial denitrification when soil water is transformed to ice. Effects of freezing on the soil physical environment may influence rates of microbial denitrification at sub-zero soil temperatures.

Calculation of soil \%WFPS becomes less tractable at subzero soil temperatures because the majority of liquid water becomes ice, rendering changes in bulk density (Kay et al., 1985), hydraulic conductivity (Pikul and Allmaras, 1985), pore space volume (Loch and Kay, 1978), and water content (Pikul et al., 1989). Liquid water in frozen soil is mobile (Pikul and Allmaras, 1985) and flows along unfrozen liquid water channels (Edwards and Cresser, 1992), which change in thickness as temperature decreases (Anderson and Hoeckstra, 1965). Formation of ice pushes soil particles apart to increase soil pore size (Loch and Miller, 1975), and ice lenses forms to create additional pores (Kay et al., 1985). The percent of water occupying soil pores is not constant because liquid water content and soil pore space are not constant at sub-zero soil temperatures. 


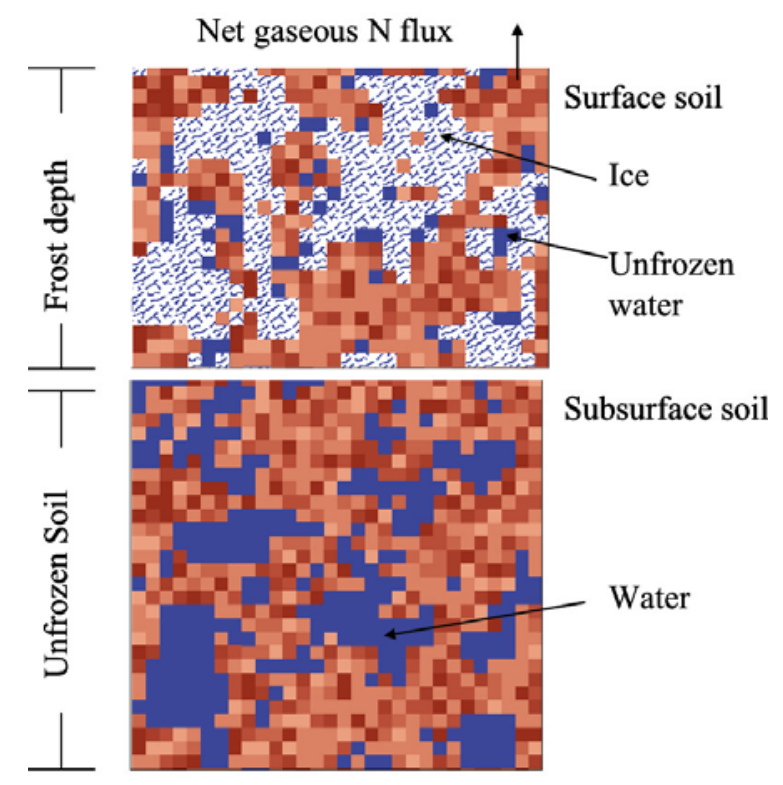

Figure 1. Conceptual illustration of a soil column where ice and unfrozen liquid water exist in surface soil (frozen soil depth varies with frost depth) and liquid water exists in subsurface soil. Brown represents soil, blue represents water, and white with blue represents ice.

The presence of both ice and unfrozen water in soil could enhance denitrification at oxic/sub-oxic interfaces controlled by the thermal gradient. Oxic/sub-oxic interfaces facilitate transport of oxidized forms of $\mathrm{N}$ from oxic to sub-oxic zones (Seitzinger et al., 2006). If these interfaces are present in frozen soil, then the amount of ice versus unfrozen water could influence denitrification rates. However, the presence of oxic/sub-oxic interfaces is not likely to remain static in frozen soil because the amount of unfrozen water, the thickness of the water films, the size of transport channels, and hydraulic conductivity are controlled by soil temperature (Hoeckstra, 1966; Pikul and Allmaras, 1985). The temperature gradient continuously transforms ice to films of water (Kay et al., 1985), potentially creating sites for denitrification at oxic/sub-oxic interfaces.

Freezing also induces changes in soil structural stability (Bullock et al., 1988; Lehrsch et al., 1990), which interacts with water and temperature to affect soil pore space. Liquid water is replaced by ice lenses that weaken soil aggregates (Bullock et al., 1988; Edwards and Cresser, 1992; Lehrsch et al., 1990). As the frost front moves into the soil and the majority of soil water is transformed to ice, soil cohesion is lost to shearing forces (Bullock et al., 1988). Slightly soluble chemicals precipitate at the surface of soil particles. As the thermal gradient vacillates diurnally and seasonally, ice crystals collapse and return to unfrozen water. As freezing progresses deeper into the soil, water also migrates upward towards the freezing front to increase water content near the surface (Hoeckstra, 1966). Soil aggregates frozen at high water contents $(>15 \% \mathrm{v} / \mathrm{v})$ will be more strongly affected by freezing than soil aggregates frozen at lower water contents (Lehrsch et al., 1990), with greater loss of aggregate stability and cohesion across a wide range of soil series (Bullock et al., 1988).

Disruption to the soil matrix as a result of freezing, as described above, is complex and dynamic. Freezing affects soil volume, migration of water, aggregate stability, precipitation of solutes, ice crystal formation, and ice crystal collapse - all of which could alter soil $\mathrm{O}_{2}$ status. Microbes can remain physiologically active when films of unfrozen soil water are present (Mikan et al., 2002; Priemé and Christensen, 2001; Rivkina et al., 2000), and denitrification has been measured in soils at $-2{ }^{\circ} \mathrm{C}$ (Dorland and Beauchamp, 1991; Phillips, 2007). Initial \%WFPS at freezing may be fundamental to understanding interactions between soil physics and soil microbial activity, but diffusion of $\mathrm{O}_{2}$ may be limited by other factors. Current $\%$ WFPS thresholds for denitrification (Firestone and Davidson, 1989) in frozen soil may need adjustment and/or other potential factors (e.g. thermal gradient, ice-filled pore space) considered.

\section{SOIL ORGANIC CARBON IN FROZEN SOIL}

Organic $\mathrm{C}$ often limits denitrification in cropped soils at soil temperatures above $0{ }^{\circ} \mathrm{C}$ (Beauchamp et al., 1989; Burford and Bremner, 1975; McCarty and Bremner, 1993; Sainz Rozas et al., 2001), but it is uncertain how organic $C$ influences denitrification below $0{ }^{\circ} \mathrm{C}$. Alternatively, studies of aerobic microbial respiration below $0{ }^{\circ} \mathrm{C}$ suggest soil organic $\mathrm{C}$ can limit microbial activity (Feng et al., 2007; Michaelson and Ping, 2003; Priemé and Christensen, 2001; Schimel and Clein, 1996) and that aggregate disruption from freezing releases potentially mineralizable $\mathrm{C}$ to microbes when soils thaw (Christensen and Tiedje, 1990; Priemé and Christensen, 2001). Greater microbial respiration observed following freeze-thaw cycles (Christensen and Tiedje, 1990; Jacinthe et al., 2002; Mikan, 2002; Teepe et al., 2004) may be linked to soil organic C (Breitenbeck and Bremmer, 1986; Mikan, 2002; Schimel and Clein, 1996; Skogland et al., 1988), since freeze-thaw events positively influence amounts of small, hydrophilic compounds (Michaelson and Ping, 2003) and phospholipid fatty acids (Feng et al., 2007). Suggested mechanisms for C availability following freezing and thawing include rupture of cellular membranes in microbial biomass (Skogland et al., 1988), the release of organic matter previously bound in aggregates (Christensen and Christensen, 1991), and exposure of fresh reactive surfaces (Edwards and Cresser, 1992). In addition, thawing may enhance the availability of $\mathrm{C}$ required for anaerobic respiration through the collapse of ice crystals and diffusion of substrate to anoxic microsites.

Rarely are effects of freezing on microbial activity separated into components of $\mathrm{C}$ availability versus physical soil disturbance. Reported pulses of aerobic microbial respiration in frozen soils may be due to disturbance from aggregate disruption (Edwards and Cresser, 1992), release of organic C (Christensen and Christensen, 1991; Myrold and Tiedje, 1985; Schimel and Clein, 1996), changes in the form of organic C (Feng et al., 2007), or to changes in the diffusion of gases or solutes in frozen soil. The causative factor of respiratory 
activities (physical disturbance, substrate amount/form, diffusion) likely contributes to the magnitude and duration of observed pulses. This may be critical to denitrification questions in agronomy because physical disturbances from freezing can be modified, to some extent, with tillage and residue management. Diurnal and seasonal soil temperature extremes are modulated and depth to frost is reduced with standing stubble (Pikul et al., 1986), with mulch application (Kohnke and Werkhoven, 1963), and with reduced tillage (Kay et al., 1985). On the other hand, carbon can limit denitrification (McCarty and Bremner, 1993), and addition of plant residues can promote denitrification activity (Aulakh et al., 1984; McCarty and Bremner, 1993). Laboratory studies using soils from notill cropping systems point to greater soil $\mathrm{C}$ as the reason for higher denitrification rates, compared to conventional tillage (Aulakh et al., 1984; Liu et al., 2007; van Bochove et al., 2000). Understanding and quantifying effects of management on denitrification in frozen soil require separation of physical disturbance (loss of aggregate cohesion and stability) from release and transport of organic $\mathrm{C}$ potentially bound in soil aggregates. From here, if organic $\mathrm{C}$ is limiting denitrification, both tillage and residue management recommendations could be balanced to potentially reduce denitrification rates.

\section{NITROGEN IN FROZEN SOILS}

Effects of fertilizer-N on denitrification have been studied extensively (see review by Hofstra and Bouwman, 2005). Fertilized soil at high \%WFPS will promote facultative anaerobic bacteria to reduce $\mathrm{N}$ oxides and consume organic matter (Firestone and Davidson, 1989; Mulvaney et al., 1997). The magnitude and duration of $\mathrm{NO}_{3}^{-}$additions varies with soil texture, $\mathrm{pH}$, climate, crop, management, etc. (Jungkunst et al., 2006; Kaiser et al., 1998; Nieder et al., 1989; Sainz Rozas et al., 2001). It is generally accepted that cropped soils with high rates of fertilizer- $\mathrm{N}$ inputs generally exhibit higher denitrification rates than soils not receiving fertilizer-N additions (Aulakh et al., 2001; Barton et al., 1999; Jarvis et al., 1991; Kaiser et al., 1998). Manures and animal slurries amendments also enhance denitrification rates (Calderón et al., 2004; Ginting et al., 2003; Lessard et al., 1996; Mogge et al., 1999; Paul et al., 1993; Petersen, 1999). The proportion of fertilizer$\mathrm{N}$ denitrified in crop fields varies widely across soil series and climates (see review by Nieder et al., 1989), with $2.5 \%$ reported in Colorado, USA (Mosier et al., 1986) and 60\% reported in Denworth, UK (Colbourn et al., 1984).

The effect of fertilizer-N application on denitrification rates in cropped soils during the winter is less known, particularly when soils are frozen. Field studies instead have reported significant emissions of $\mathrm{N}_{2} \mathrm{O}$ (Goossens et al., 2001; Maggiotto and Wagner-Riddle, 2001; Ruser et al., 2001; Wagner-Riddle et al., 1997). Nitrous oxide studies are labor intensive, and microbial activity in frozen soil is often assumed to be negligible; consequently $\mathrm{N}_{2} \mathrm{O}$ flux data collected at the surface of frozen soil are rare (Phillips, 2007; Röver et al., 1998). Evidence of greater microbial $\mathrm{N}_{2} \mathrm{O}$ production in fertilized soil during winter suggests that denitrification may occur in anoxic soil microsites at low soil temperatures. Manure amendments were found to increase $\mathrm{N}_{2} \mathrm{O}$ flux and denitrification in the field and in soil cores (30-cm depth) incubated at sub-zero soil temperatures (Phillips, 2007), but further research is needed to determine the geographic prevalence of denitrification in frozen soils, and how form and timing of fertilizer-N application might alter gaseous $\mathrm{N}$ losses in winter.

Determining the location of denitrification in the soil profile is also paramount to understanding $\mathrm{N}$ management in winter (Fig. 1). Denitrification in the soil profile could occur (a) below the freezing front in subsurface soil, (b) in the frozen surface soil, (c) at the interface between frozen/unfrozen soils, or (d) throughout the profile in both frozen and unfrozen soil. In each case, the distance denitrification products would need to travel upward to the surface would significantly affect emissions at the surface because there may be opportunities for complete reduction of $\mathrm{NO}$ or $\mathrm{N}_{2} \mathrm{O}$ to $\mathrm{N}_{2}$ as they migrate from below the freezing front to the surface. Further, as suggested earlier, denitrification controls in the frozen surface soil are likely different from denitrification controls in the unfrozen subsurface. Snow cover, residue cover, and tillage will reduce the frozen soil depth; consequently, understanding the vertical distribution of denitrification activity within the soil profile will point to how management might influence $\mathrm{N}$ emissions at the soil surface by manipulating soil temperature.

\section{CONCLUSION}

What is not known about denitrification in cropped soils at sub-zero soil temperatures far exceeds what is known. Physical differences induced by soil freezing suggest use of \%WFPS as a proxy for soil aerobic status is insufficient for predicting heterotrophic anaerobic respiration below $0{ }^{\circ} \mathrm{C}$. Organic $\mathrm{C}$ may limit aerobic microbial respiration below $0{ }^{\circ} \mathrm{C}$, calling into question if organic $\mathrm{C}$ might also limit anaerobic respiration. If so, management practices implemented in autumn (e.g., residue incorporation, compost or fertilizer-N application) could promote $\mathrm{N}$ and $\mathrm{C}$ losses via denitrification, with important agronomic implications (Fig. 2). Moreover, observed fluxes of $\mathrm{N}_{2} \mathrm{O}$ in fertilized cropped soils during the dormant season point to potential losses of fertilizer- $\mathrm{N}$ inputs via denitrification, but total annual $\mathrm{N}$ losses need quantification. The agronomic importance of timing and form of fertilizer$\mathrm{N}$ during the growing season is well known. Less known is how post-season $\mathrm{N}$ application influences the $\mathrm{N}$-budget and plant-available $\mathrm{N}$ the following spring. Denitrified $\mathrm{N}$ losses from cropping systems at sub-zero soil temperatures may or may not amount to a significant portion of the $\mathrm{N}$ budget. However, the preponderance of the evidence suggests denitrification should not be considered negligible without further investigation.

A number of agronomic research questions have been raised with respect to the three factors required for denitrification (limited $\mathrm{O}_{2}$, organic $\mathrm{C}, \mathrm{NO}_{3}^{-}$), a few of which are summarized below.

- How much $\mathrm{N}$ is denitrified during the off-season, particularly when soils are frozen? 
Crop Management Practices and Potential Effects on Denitrification in Frozen Soil

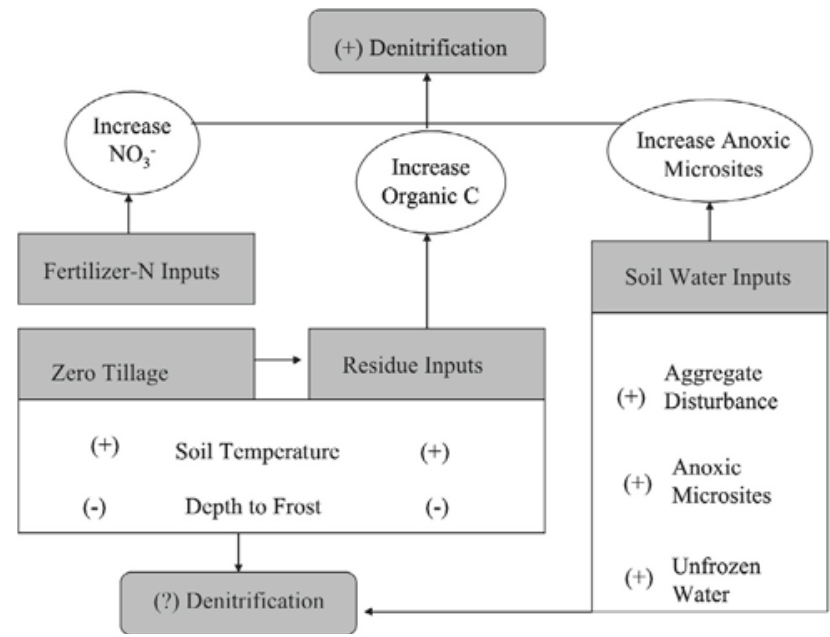

Figure 2. Summary of potential crop management effects on denitrification in frozen soil. Positive effects are indicated with $(+)$ and negative effects by (-). Some of the indirect effects of management on denitrification in soil, designated by (?), are unknown.

- How does water content below $0{ }^{\circ} \mathrm{C}$ influence denitrification compared to above $0{ }^{\circ} \mathrm{C}$ ?

- What is the $\mathrm{O}_{2}$ status of frozen soil and how does this change with the advancement of the freezing front?

- How does migration of water below $0{ }^{\circ} \mathrm{C}$ influence denitrification?

- Is denitrification in frozen soil limited by organic C? How available is organic $\mathrm{C}$ to microbes below $0{ }^{\circ} \mathrm{C}$ ?

- How is substrate transport affected by soil comprised of ice and unfrozen soil water? How available are solutes to microbes in frozen soil?

- How is fertilizer-N transformed in frozen soil? At what point in the $\mathrm{N}$-cycle is $\mathrm{N}$ transformation inhibited by freezing temperatures?

- Does the type of fertilizer-N applied to crop fields (e.g., compost, urea, anhydrous ammonium) influence denitrification in winter?

- Do plant residue fermentation products enhance denitrification below $0{ }^{\circ} \mathrm{C}$ ?

- Does denitrification occur in both the frozen soil near the surface and in the unfrozen subsurface soil?

The evidence indicates microbial denitrification occurs during the winter in previously-cropped soils at sub-zero soil temperatures, and the potential exists for some mediation with management. However, management studies should be preceded by basic knowledge of how frozen soil conditions alter soil $\mathrm{O}_{2}$ status and anaerobic transformation of $\mathrm{NO}_{3}^{-}$to gaseous $\mathrm{N}_{2} \mathrm{O}$ and $\mathrm{N}_{2}$. From there, questions of soil $\mathrm{pH}$, texture, residue quantity and quality, fertilizer- $\mathrm{N}$ form and timing, etc., can be more parsimoniously addressed. Potential economic and climate change implications warrant continued, mechanistic research.
Acknowledgements: Special thanks to Drs. Joe Pikul, Steve Merrill, Bill Schlesinger, Steve Whalen, and Mark Liebig for their valuable comments.

\section{REFERENCES}

Anderson D.M., Hoeckstra P. (1965) Migration of interlamellar water during freezing and thawing of Wyoming bentonite, Soil Sci. Soc. Proc. 29, 498-504.

Aulakh M.S., Rennie D.A., Paul A. (1984) The influence of plant residues on denitrification rates in conventional and zero tilled soils, Soil Sci. Soc. Am. J. 48, 790-794.

Aulakh M., Khera T., Doran J., Bronson K. (2001) Denitrification, $\mathrm{N}_{2} \mathrm{O}$ and $\mathrm{CO}_{2}$ fluxes in rice-wheat cropping system as affected by crop residues, fertilizer $\mathrm{N}$ and legume green manure, Biol. Fert. Soils 34 , $375-389$.

Barton L., McLay C.D.A., Schipper L.A., Smith C.T. (1999) Annual denitrification rates in agricultural and forest soils: a review, Aust. J. Soil Res. 37, 1073-1093.

Bateman E.J., Baggs E.M. (2005) Contributions of nitrification and denitrification to $\mathrm{N}_{2} \mathrm{O}$ emissions from soils at different water-filled pore space, Biol. Fert. Soils 41, 379-388.

Beauchamp E.G., Trevors J.T., Paul J.W. (1989) Carbon sources for bacterial denitrification, Adv. Soil Sci. 10, 113-142.

Bouwman A.F., Van der Hoek K.W., Olivier J.G.J. (1995) Uncertainties in the global source distribution of nitrous oxide, J. Geophys. Res. 100, 2785-2800.

Bouwman A.F., Van Drecht G., Knoop J.M., Beusen A.H.W., Meinardi C.R. (2005) Exploring changes in river nitrogen export to the world's oceans, Global Biogeochem. Cycles 19, DOI: 10.1929/2004GB0002314.

Breitenbeck G.A., Bremmer J.M. (1986) Effects of rate and depth of fertilizer application on emission of nitrous oxide from soil fertilized with anhydrous ammonia, Biol. Fert. Soils 2, 201-204.

Bullock M.S., Kemper W.D., Nelson S.D. (1988) Soil cohesion as affected by freezing, water content, time and tillage, Soil Sci. Soc. Am. J. 52, 770-776.

Burford J.R., Bremner J.M. (1975) Relationships between the denitrification capacities of soils and total, water-soluble and readily decomposable soil organic matter, Soil Biol. Biochem. 7, 389-394.

Calderón F.J., McCarty G.W., Van Kessel J.A.S., Reeves III J.B. (2004) Carbon and nitrogen dynamics during incubation of manured soil, Soil Sci. Soc. Am. J. 68, 1592-1599.

Cassman K.G., Dobermann A., Walters D.T. (2002) Agroecosystems, nitrogen-use efficiency, and nitrogen management, Ambio 31, 132140.

Christensen S., Tiedje T. (1990) Brief and vigorous $\mathrm{N}_{2} \mathrm{O}$ production by soil at spring thaw, J. Soil Sci. 41, 1-4.

Christensen S., Christensen B.T. (1991) Organic matter available for denitrification in different soil fractions: effect of freeze/thaw cycles and straw disposal, J. Soil Sci. 42, 637-647.

Clein J.S., Schimel J.P. (1995) Microbial activity of tundra and taiga soils at sub-zero temperatures, Soil Biol. Biochem. 9, 1231-1234.

Colbourn P., Iqbal M.M., Harper W. (1984) Estimation of the total gaseous nitrogen losses from clay soils under laboratory and field conditions, J. Soil Sci. 35, 11-22.

Davidson E.A. (1991) Fluxes of nitrous oxide and nitric oxide from terrestrial ecosystems, in: Roger J.E., Whitman W.G. (Eds.), Microbial Production and Consumption of Greenhouse Gases: Methane, Nitrogen Oxides, and Halomethanes, American Society for Microbiology, Washington, DC, pp. 219-235. 
Davidson E.A., Seitzinger S. (2006) The enigma of progress in denitrification research, Ecol. Appl. 16, 2057-2063.

Davidson E.A., Keller M., Erickson H.E., Verchot L.V., Veldkamp E. (2000) Testing a conceptual model of soil emissions of nitrous and nitric oxides, Bioscience 50, 667-680.

Dobbie K.E., McTaggart I.P., Smith K.A. (1999) Nitrous oxide emissions from intensive agricultural systems: Variations between crops and seasons, key driving variables, and mean emission factors, J. Geophys. Res. D: Atmospheres 104, 26891-26899.

Dobbie K.E., Smith K.A. (2003) Nitrous oxide emission factors for agricultural soils in Great Britain: the impact of soil water-filled pore space and other controlling variables, Global Change Biol. 9, 204218.

Dorland S., Beauchamp E.G. (1991) Denitrification and ammonification at low soil temperatures, Can. J. Soil Sci. 71, 293-303.

Edwards A.C., Cresser M.S. (1992) Freezing and its effect on chemical and biological properties of soil, Adv. Soil Sci. 18, 59-79.

Feng X., Nielsen L.L., Simpson M.J. (2007) Responses of soil organic matter and microorganisms to freeze-thaw cycles, Soil Biol. Biochem. 39, 2027-2037.

Firestone M.K., Firestone R.B., Tiedje J.M. (1980) Nitrous oxide from soil denitrification: factors controlling its biological production, Science 208, 749-751.

Firestone M.K., Davidson E.A. (1989) Microbial basis of NO and $\mathrm{N}_{2} \mathrm{O}$ production and consumption in soil, in: Andreae M.O., Schimel D.S. (Eds.), Exchange of Trace Gases between Terrestrial Ecosystems and the Atmosphere, John Wiley and Sons, New York, pp. 7-21.

Forster P., Ramaswamy V., Artaxo P., Berntsen T., Betts R., Fahey D.W., Haywood J., Lean J., Lowe D.C., Myhre G., Nganga J., Prinn R., Raga G., Schulz M., Van Dorland R. (2007) Changes in Atmospheric Constituents and in Radiative Forcing, in: Solomon S., Qin D., Manning M., Chen Z., Marquis M., Avery K.B., Tignor M., Miller H.L. (Eds.), Climate Change 2007: The Physical Science Basis. Contribution of Working Group I to the Fourth Assessment Report of the Intergovernmental Panel on Climate Change, Cambridge University Press, Cambridge United Kingdom and New York, NY, USA, pp. 129-234.

Galloway J.N., Dentener F.J., Capone D.G., Boyer E.W., Howarth R.W., Seitzinger S.P., Asner G.P., Cleveland C.C., Green P.A., Holland E.A., Karl D.M., Michaels A.F., Porter J.H., Townsend A.R., Vöosmarty C.J. (2004) Nitrogen Cycles: Past, Present, and Future, Biogeochem. 70, 153-226.

Ginting D., Kessavalou A., Eghball B., Doran J.W. (2003) Greenhouse gas emissions and soil indicators four years after manure and compost applications, J. Environ. Qual. 32, 23-32.

Goossens A., Visscher A., Boeckx P., Cleemput O. (2001) Two-year field study on the emission of $\mathrm{N}_{2} \mathrm{O}$ from coarse and middle-textured Belgian soils with different land use, Nutr. Cycl. Agroecosys. 60, 23-34.

Hoeckstra P. (1966) Moisture movement in soils under temperature gradients with the cold-side temperature below freezing, Water Resour. Res. 2, 241-250.

Hofstra N., Bouwman A. (2005) Denitrification in agricultural soils: Summarizing published data and estimating global annual rates, Nutr. Cycl. Agroecosys. 72, 267-278.

Hulth S., Aller R.C., Gilbert F. (1999) Coupled anoxic nitrification/manganses reduction in marine sediments, Geochim. Cosmochim. Ac. 63, 49-66.

Jarvis S., Barraclough D., Williams J., Rook A. (1991) Patterns of denitrification loss from grazed grassland: Effects of $\mathrm{N}$ fertilizer inputs at different sites, Plant Soil 131, 77-88.

Jungkunst H.F., Freibauer A., Neufeldt H., Bareth G. (2006) Nitrous oxide emissions from agricultural land use in Germany-a synthesis of available annual field data, J. Plant Nutr. Soil Sci. 169, 341-351.
Kaiser E.A., Kohrs K., Kücke M., Schnug E., Heinemeyer O., Munch J.C. (1998) Nitrous oxide release from arable soil: Importance of $\mathrm{N}$-fertilization, crops and temporal variation, Soil Biol. Biochem. $30,1553-1563$.

Kay B.D., Grant C.D., Groenevelt P.H. (1985) Significance of ground freezing on soil bulk density under zero tillage, Soil Sci. Soc. Am. J. 49, 973-978.

Kohnke H., Werkhoven C.H. (1963) Soil temperature and soil freezing as affected by an organic mulch, Soil Sci. Soc. Proc. 27, 13-17.

Kuypers M.M.M., Lavik G., Woebken D., Schmid M., Fuchs B.M., Amann R., Jørgensen B.B., Jetten M.S.M. (2005) Massive nitrogen loss from the Benguela upwelling system through anaerobic ammonium oxidation, Proc. Natl. Acad. Sci. (USA) 102, 6478-6483.

Lehrsch G.G., Sojka R.E., Carter D.L., Jolley P.M. (1990) Freezing effects on aggregate stability affected by texture, mineralogy, and organic matter, Soil Sci. Soc. Am. J. 55, 1401-1406.

Lessard R., Rochette P., Gregorich E.G., Pattey E., Desjardins R.L. (1996) Nitrous oxide fluxes from manure-amended soul under maize, J. Environ. Qual. 25, 1371-1377.

Liu X.J., Mosier A.R., Halvorson A.D., Reule C.A., Zhang F.S. (2007) Dinitrogen and $\mathrm{N}_{2} \mathrm{O}$ emissions in arable soils: Effect of tillage, $\mathrm{N}$ source and soil moisture, Soil Biol. Biochem. 39, 2362-2370.

Loch J.P.G., Miller R.D. (1975) Tests of the concept of secondary frost heaving, Soil Sci. Soc. Proc. 39, 1036-1041.

Loch J.P.G., Kay B.D. (1978) Water redistribution in partially frozen, saturated silt under several temperature gradients and overburden loads, Soil Sci. Soc. Am. J. 42, 400-406.

Maggiotto S.R., Wagner-Riddle C. (2001) Winter and spring thaw measurements of $\mathrm{N}_{2} \mathrm{O}$, NO and NOx fluxes using a micrometeorological method, Water Air Soil Poll. 1, 89-98.

McCarty G.W., Bremner J.M. (1993) Factors affecting the availability of organic carbon for denitrification of nitrate in subsoils, Biol. Fert. Soils 15, 132-136.

Michaelson G.J., Ping C.L. (2003) Soil organic carbon and $\mathrm{CO}_{2}$ respiration at subzero temperature in soils of Arctic Alaska, J. Geophys. Res. 108, DOI: 10.1029/2001JD000920.

Mikan C.J., Schimel J.P., A.P. Doyle (2002) Temperature controls of microbial respiration in arctic tundra soils above and below freezing, Soil Biol. Biochem. 34, 1785-1795.

Mogge B., Kaiser E., Munch J. (1999) Nitrous oxide emissions and denitrification $\mathrm{N}$-losses from agricultural soils in the Bornhöved Lake region: influence of organic fertilizers and land-use, Soil Biol. Biochem. 31, 1245-1252.

Mosier A., Guenzi W.D., Schweizer E.E. (1986) Soil losses of dinitrogen and nitrous oxide from irrigated crops in northeastern Colorado, Soil Sci. Soc. Am. J. 50, 344-348.

Mulvaney R.L., Khan S.A., Mulvaney C.S. (1997) Nitrogen fertilizers promote denitrification, Biol. Fert. Soils 24, 211-220.

Myrold D.D., Tiedje T. (1985) Diffusional constraints on denitrification in soil, Soil Sci. Soc. Am. J. 49, 651-657.

Nieder R., Schollmayer G., Richter J. (1989) Denitrification in the rooting zone of cropped soils with regard to methodology and climate: A review, Biol. Fert. Soils 8, 219-226.

Parkin T.B. (1987) Soil microsites as a source of denitrification variability, Soil Sci. Soc. Am. J. 51, 1194-1199.

Paul J.W., Beauchamp E.G., Zhang X. (1993) Nitrous oxide and nitric oxide emissions during nitrification and denitrification from manureamended soil in the laboratory, Can. J. Soil Sci. 73, 539-553.

Petersen S.O. (1999) Nitrous oxide emissions from manure and inorganic fertilizers applied to spring barley, J. Environ. Qual. 28, 1610-1618.

Phillips R.L. (2007) Organic agriculture and nitrous oxide emissions at sub-zero soil temperatures, J. Environ. Qual. 36, 23-30. 
Pikul J.L., Allmaras R.R. (1985) Hydraulic potential in unfrozen soil in response to diurnal freezing and thawing of the soil surface, Trans. ASAE 28, 164-168.

Pikul J.L., Zuzel J.F., Greenwalt R.N. (1986) Formation of soil frost as influenced by tillage and residue management, J. Soil Water Cons. 41, 196-199.

Pikul J.L., Boersma L., Rickman R.W. (1989) Temperature and water profiles during diurnal soil freezing and thawing: field measurements and simulation, Soil Sci. Soc. Am. J. 53, 3-10.

Prather M., Ehhalt D., Dentener F., Derwent J., Dlugokencky E., Holland E.A., Isaksen I., Katima J., Kirchhoff P., Matson P.A., Midgley P., Wang M. (2001). Atmospheric chemistry and greenhouse gases, in: Houghton J.T., Ding Y., Griggs D.J., Noguer M., van der Linden P.J., Dai X., Maskell K., Johnson C.A. (Eds.), Climate change 2001: the scientific basis. Contribution of Working Group I to the Third Assessment Report of the Intergovernmental Panel on Climate Change, Cambridge University Press, Cambridge, UK, pp. 240 287.

Price P.B., Sowers T. (2004) Temperature dependence of metabolic rates of rmicrobial growth, maintenance, and survival, Proc. Natl Acad. Sci. 101, 4631-4636.

Priemé A., Christensen S. (2001) Natural perturbations, drying-wetting and freezing-thawing cycles, and the emission of nitrous oxide, carbon dioxide and methane from farmed organic soils, Soil Biol. Biochem. 33, 2083-2091.

Rivkina E., Friedmann E., McKay C., Gilichinsky D. (2000) Metabolic activity of permafrost bacteria below the freezing point, Appl. Environ. Microbiol. 66, 3230-3233.

Röver M., Heinemeyer O., Kaiser E.A. (1998) Microbial induced nitrous oxide emissions from an arable soil during winter, Soil Biol. Biochem. 30, 1859-1865.

Ruser R., Flessa H., Schilling R., Beese F., Munch J.C. (2001) Effect of crop-specific field management and $\mathrm{N}$ fertilization on $\mathrm{N}_{2} \mathrm{O}$ emissions from a fine-loamy soil, Nutr. Cycl. Agroecosys. 59, 177-191.
Sainz Rozas H.R., Echeverría H.E., Picone L.I. (2001) Denitrification in maize under no-tillage: Effect of nitrogen rate and application time, Soil Sci. Soc. Am. J. 65, 1314-1323.

Schimel D.S., Clein J.S. (1996) Microbial response to freeze-thaw cycles in tundra and taiga soils, Soil Biol. Biochem. 28, 1061-1066.

Seitzinger S., Harrison J.A., Bohlke J.K., bouwman A.F., Lowrance R., Peterson B., Tobias C., Van Drecht G. (2006) Denitrification across landscapes and waterscapes: A synthesis, Ecol. Appl. 16, 20642090.

Sexstone A.J., Revsbech N.P., Parkin T.B., Tiedje T. (1985) Direct measurement of oxygen profiles and denitrification rates in soil aggregates, Soil Sci. Soc. Am. J. 49, 645-651.

Sexstone A.J., Parkin T.B., Tiedje T. (1988) Denitrification response to soil wetting in aggregated and unaggregated soil, Soil Biol. Biochem. 20, 767-769.

Skogland T., Lomeland S., Goksoyr J. (1988) Respiratory burst after freezing and thawing of soil: experiments with soil bacteria, Soil Biol. Biochem. 20, 851-856.

Smith K.A. (1980) A model of the extent of anaerobic zones in aggregated soils, and its potential application to estimates of denitrification, J. Soil Sci. 31, 263-277.

Teepe R., Vor A., Beese F., Ludwig B. (2004) Emissions of $\mathrm{N}_{2} \mathrm{O}$ from soils during cycles of freezing and thawing and the effects of soil water, texture and duration of freezing, Eur. J. Soil Sci. 55, 357365.

van Bochove E., Prévost D., Pelletier F. (2000) Effects of freeze thaw and soil structure on nitrous oxide produced in a clay Soil, Soil Sci. Soc. Am. J. 4, 138-143.

Wagner-Riddle J.C., Thurtell G.W., Kidd G.K., Beauchamp E.G., Sweetman R. (1997) Estimates of nitrous oxide emissions from agricultural fields over 28 months, Can. J. Soil Sci. 77, 135-144. 